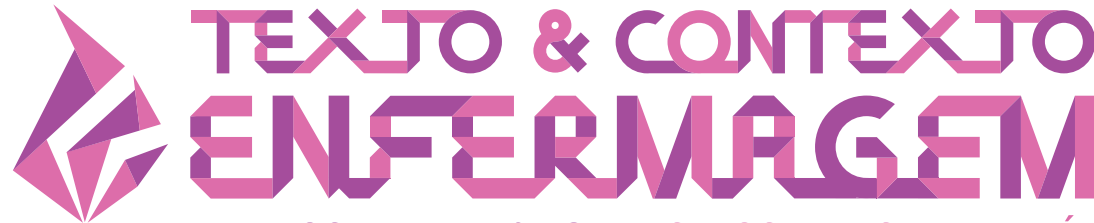

TEXT \& CONTEXT NURSING TEXTO \& CONTEXTO ENFERMERÍA

\section{HEALTH LITERACY OF INDIVIDUALS UNDERGOING DIALYSIS THERAPY}

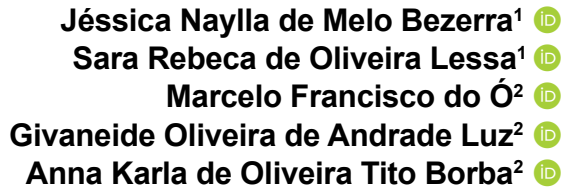

1 Universidade Federal de Pernambuco, Hospital das Clínicas, Recife, PE, Brasil 2 Universidade Federal de Pernambuco, Departamento de Enfermagem. Recife, PE, Brasil

\begin{abstract}
Objective: to assess the functional levels of health literacy in individuals undergoing dialysis.

Method: a cross-sectional study with 42 patients of the Nephrology Unit of a public hospital in Recife, Brazil, from May to August 2016. Data were collected through scripted interviews and chart analysis. Functional health literacy was measured using the Brazilian version of the ShortTest of Functional Health Literacy in Adults questionnaire. Data analysis was performed using the Statistical Package for Social Sciences (SPSS ${ }^{\circledR}$ ) software, version 18.0, with a univariate analysis to verify the association between independent variables and functional health literacy levels using Fisher's exact test.

Results: $80.9 \%$ of the patients presented inadequate health literacy and $19.1 \%$ presented adequate health literacy. The number of correct answers remained between 0-18 in the reading comprehension and in the scheduling appointment card. Among the independent variables, only marital status $(p$-value $=0.018)$ and personal income $(p$-value $=0.009)$ were factors associated with the worst scores in the test, indicating that these variables influence the increase in inadequate literacy.

Conclusion: the prevalence of inadequate functional literacy was high, reflecting difficulties in understanding and processing health information, which may interfere with therapeutic management and self-care.
\end{abstract}

DESCRIPTORS: Health literacy. Kidney disease. Dialysis. Knowledge. Self-care. 


\section{LETRAMENTO EM SAÚDE DOS INDIVÍDUOS SUBMETIDOS À TERAPIA DIALÍTICA}

\section{RESUMO}

Objetivo: analisar os níveis de letramento funcional em saúde dos indivíduos em tratamento dialítico. Método: estudo transversal com 42 pacientes assistidos na Unidade de Nefrologia de um hospital da rede pública em Recife, Brasil, no período de maio a agosto de 2016. Os dados foram coletados por meio de entrevista com roteiro estruturado e análise de prontuário. O letramento funcional em saúde foi mensurado pela versão brasileira do questionário Brief Test of Functional Health Literacy in Adults. A análise dos dados foi por meio do software estatístico Statistical Package for the Social Sciences $\left(\right.$ SPSS $^{\circledR}$ ) versão 18.0, com análise univariada para verificar associação entre as variáveis independentes com os níveis de letramento funcional em saúde através do teste Exato de Fisher.

Resultados: constatou-se que $80,9 \%$ dos pacientes apresentaram letramento em saúde inadequado e 19,1\% adequado. O número de acertos se manteve entre 0-18 na compreensão de leitura e no cartão de aprazamento das consultas. Dentre as variáveis independentes, apenas estado civil ( $p$-valor $=0,018)$ e renda pessoal $(p$-valor=0,009) apresentaram-se como fatores associados aos piores escores no teste, indicando que essas variáveis influenciam no aumento do letramento inadequado. Conclusão: a prevalência de letramento funcional inadequado foi alta, refletindo as dificuldades de compreensão e processamento de informações em saúde, podendo interferir no manejo terapêutico e no autocuidado.

DESCRITORES: Alfabetização em saúde. Doença renal. Diálise. Conhecimento. Autocuidado.

\section{LETRA EN SALUD DE LOS INDIVIDUOS SUBMETIDOS A LA TERAPIA DIALÍTICA}

\section{RESUMEN}

Objetivo: analizar los niveles de letra funcional en salud de los individuos en tratamiento dialítico. Método: estudio transversal con 42 pacientes asistidos en la Unidad de Nefrología de un hospital de la red pública en Recife, Brasil, en el período de mayo a agosto de 2016. Los datos fueron recolectados por medio de entrevista con guión estructurado y análisis de prontuario. El cuadro funcional en salud fue medido por la versión brasileña del cuestionario Brief Test of Functional Health Literacy in Adults. El análisis de los datos fue a través del software estadístico Statistical Package for the Social Sciences (SPSS ${ }^{\circledR}$ ) versión 18.0, con análisis univariado para verificar asociación entre las variables independientes con los niveles de letra funcional en salud a través del test Exacto de Fisher. Resultados: se constató que el $80,9 \%$ de los pacientes presentaron letra en salud inadecuada y el $19,1 \%$ adecuado. El número de aciertos se mantuvo entre 0-18 en la comprensión de lectura y en la tarjeta de consulta de las consultas. En las variables independientes, sólo estado civil ( $p$-valor=0,018) $y$ renta personal ( $p$-valor $=0,009$ ) se presentaron como factores asociados a los peores escores en el test, indicando que esas variables influencian en el aumento del letramento inadecuado.

Conclusión: la prevalencia de letra funcional inadecuada fue alta, reflejando las dificultades de comprensión y procesamiento de informaciones en salud, pudiendo interferir en el manejo terapéutico y en el autocuidado.

DESCRIPTORES: Alfabetización en salud. Enfermedad renal. Diálisis. Conocimiento. Autocuidado. 


\section{INTRODUCTION}

Chronic renal disease (CRD) is considered a worldwide public health problem due to its high morbidity and mortality. ${ }^{1}$ It can be defined as the progressive and irreversible loss of renal function for a period equal to or greater than three months. It is characterized by structural and/or functional abnormalities of the kidney, with or without presence of a decrease in Glomerular Filtration Rate (GFR), i.e., GFR less than $60 \mathrm{ml} / \mathrm{min} / 1.73 \mathrm{~m}^{2}{ }^{2}$

According to the 2016 census of the Brazilian Nephrology Society, there are more than 750 dialysis units in Brazil, with an estimated 122,825 registered people, with a prevalence rate of 596 patients per million population ( $\mathrm{pmp}$ ) on dialysis, varying according to the region. ${ }^{3}$

The increasing number of people on dialysis therapy is associated with a significant increase in the population of patients with nephropathies, generating negative impacts on the individual, the family and the community, as well as increasing the costs of the Brazilian Unified Health System, which is responsible for providing all the treatment. ${ }^{4}$

Because it is chronic and irreversible, CRD forces the patient to change their lifestyle, including dietary re-education, water restriction, drug therapy and, in many cases, adaptation to renal replacement therapy. ${ }^{5}$

Renal replacement therapies include haemodialysis (HD) and peritoneal dialysis (PD), modalities that will be focused in this study. Such processes are characterized by the filtration and purification, in the blood, of nitrogenous compounds, such as urea and creatinine. ${ }^{6}$

Patients with nephropathies, especially those on dialysis, suffer from changes in daily routines, family and individual responsibilities due to the need for therapy and changes in lifestyle habits. With these changes, knowledge about illness and treatment become key points for maintaining self-care, which is defined as a set of actions performed by each individual for the maintenance of health and consequent adherence to therapy. ${ }^{7}$

In this context, functional literacy in health $(\mathrm{FHL})$ arises, defined as a set of skills that involve a variety of methods, such as the ability to understand and interpret health information, written or spoken, so that they can be applied in daily life. Thus, a patient with satisfactory FHL is better able to apply prophylactic and/or therapeutic measures, compared to an individual with limited literacy level, since they have the ability to communicate and use health information that facilitates indispensable decision making regarding health issues..$^{8-9}$

In the field of Nephrology, research on FHL remains scarce. Populations with a lack of basic knowledge related to health are more likely to have unfavorable clinical outcomes, especially in chronic diseases, such as CRD, ${ }^{10}$ demonstrating that, in Brazil and in developed countries, there is a high prevalence of inadequate FHL in people with nephropathies, which constitutes an obstacle to selfcare management. A study with this group of pre-dialysis patients in Brazil presented a prevalence of $100 \%$ of patients with inadequate $\mathrm{FHL}$, i.e., they care unable to process the health information received and transform them into sufficient knowledge to manage their disease. ${ }^{11}$

Thus, the research proposes to fill gaps between receiving information and adhering to selfcare, by identifying the literacy and numeracy skills of the studied group. For this purpose, the Brief Test of Functional Health Literacy in Adults B-TOFHLA was used. This instrument has already been validated in several languages and is one of the most used instruments worldwide and in Brazil for the verification of LFS in patients with nephropathy and other pathologies. ${ }^{12}$

Studies show that there are 36 health literacy verification tools with 17 registered types. Among these is the Test of Functional Health Literacy In Adults (TOFHLA) and the Rapid Estimate of Adult Literacy in Medicine (REALM) are presented as the most commonly used. ${ }^{12}$ It should be noted 
that although validated instruments allow classification of the degree of health literacy of individuals and populations, no test comprehends all the complexity of the construct, which justifies the wide variety of existing tests. ${ }^{12}$ Thus, associations between health and education were sought, considered fundamental pillars for the successful functioning of public health in the country, where the nursing profession is certainly active..$^{11-12}$

Nurses play a key role in the prevention and control of diseases and health promotion activities as they provide direct patient and community assistance through health care and education. Nursing is a professional that facilitates lifestyle and self-care by planning changed with the patient/family and evaluating the patient's performance and evolution.

Therefore, this exchange of information should be done in an objective and clear way, in order to better understand and, consequently, to comply with the proposed treatment, contributing to the improvement of quality of life and ability to cope with the disease, and thus providing the patient with the ability to manage their own health with active and reciprocal participation, making it easier to adopt self-care measures.

In this perspective, the objective of the research was to assess functional levels of health literacy in individuals with chronic renal disease undergoing dialysis treatment.

\section{METHOD}

This is a cross-sectional study conducted at the Nephrology Unit of the Hospital das Clínicas of the Federal University of Pernambuco (HC-UFPE), Recife, Brazil, which treats patients with acute or chronic renal failure with conservative treatment, haemodialysis or peritoneal dialysis. The study period was from May to August 2016 and was approved by the Ethics Research Committee. The purpose of the study was presented in writing as well as verbally to the participants and upon their agreement the Informed Consent Term (TCLE) was signed according to the National Health Council (CNS) Resolution 466/2012.

The study included 42 patients with nephropathy receiving dialysis therapy, census sample, (haemodialysis or peritoneal dialysis), 18 years of age or older; literate, with the ability to read and write; receiving dialysis for over two months. The following patients were excluded from the study; patients with neurodegenerative disease, with records in the medical records, impaired visual acuity (below 20/50), determined at the time of the study by the Snellen visual acuity score scale; and patients who used medication that compromised cognition.

Data were collected through structured interviews, which lasted one hour on average and were composed of data collection and analysis instruments. Participants were approached in the waiting room of the haemodialysis department or in the peritoneal dialysis nursing office of the institution and invited to respond to the data collection instruments.

The sociodemographic and clinical variables included in the study were: gender, age, origin, formal education, marital status, family arrangement, personal and family income, social security status, dialysis type, underlying disease, presence and type of comorbidities.

The functional health literacy was measured using the Brazilian version of the B-THOFLA questionnaire ${ }^{13}$ composed of two stages: textual comprehension and numeracy. The first stage of textual comprehension consisted of phrases about the preparation of a medical examination of the gastrointestinal tract (stomach X-ray), rights and responsibilities in relation to the health system and decision-making regarding health. These sentences contain 36 gaps in which the participant needed to choose between four alternative words that would make sense in the sentence, with only one possible correct answer. This step had to be completed within 7 minutes.

Issues related to numeracy involved the scheduling of a consultation, attention and calculation, such as medication times, the result of a laboratory test for glycaemia, as well as medication dosage, 
which had to be completed in 10 minutes. However, the examiner did not inform the participant of this time limit and, upon reaching the specified period, the test was collected. For the general test score, each correct answer in the textual comprehension equals 2 points and, for the numeracy subtest, 7 points, obtaining a total of 100 points. The scores from zero to 53 points indicate inadequate functional health literacy; between 54 and 66 points, indicate borderline functional health literacy; and between 67 and 100 points, indicate adequate functional health literacy. ${ }^{13}$

Data were analysed using the statistical Statistical Package for Social Sciences (SPSS ${ }^{\circledR}$ ) software, version 18.0 (SPSS Inc., Chicago, IL, USA) and sociodemographic, clinical characteristics and $\mathrm{FHL}$ levels were presented in absolute and relative frequencies. Continuous variables were described by median, maximum and minimum values and / or mean and standard deviation. The univariate analysis was used to verify the possible association between the independent variables and FHL levels, using Fisher's exact test. For statistical analysis, FHL was stratified into two levels: borderline/inadequate (0-66 points) and adequate (67-100 points). We chose to group the borderline and inadequate levels in the same category, considering the hypothesis that the adequate $\mathrm{FHL}$ favours adherence to the self-care of patients on dialysis therapy. The $p$ value $<0.05$ was considered statistically significant.

\section{RESULTS}

The study participants were predominantly female (61.9\%), aged over 41 years $(59.5 \%)$, residents of the capital or Metropolitan Region (83.4\%), had more than 8 years of formal education $(71.4 \%)$ and co-reside with a spouse and/or relatives (78.6\%). The majority of the participants received their personal source of income from the illness benefit $(52.4 \%)$, with a family income $R \$ 1,760$ (43.6\%). The most prevalent CRD etiology was secondary to other diseases $(38.1 \%)$, followed by systemic hypertension (31\%) and systemic lupus erythematosus (16.7\%). Haemodialysis was the predominant dialysis treatment $(71.4 \%)$. The majority of the interviewees had comorbidities $(92.9 \%)$ with hypertension $(88.1 \%$ ) being the most prevalent comorbidity (Table 1).

The average B-TOFHLA score was $48.7 \pm 21.7$ points out of 100 points. It was found that $80.9 \%$ of the patients presented inadequate health literacy (score from 0 to 66 points) and $19.1 \%$ (score from 67 to 100 points). Regarding textual comprehension, $80.5 \%$ of the patients answered between 0 and 18 questions, and, in terms of numeracy, $76.2 \%$ answered card 3 , which refers to the appointment schedule (Table 2).

Table 1 - Sociodemographic characteristics of individuals undergoing dialysis. Recife, PE, Brazil, 2016. $(n=42)$

\begin{tabular}{lc}
\hline Variables & $\mathbf{N}(\%)$ \\
\hline Sex & \\
Male & $16(38.1)$ \\
Female & $26(61.9)$ \\
Age & \\
$23-40$ years of age & $17(40.5)$ \\
$41-59$ years of age & $15(35.7)$ \\
60 year of age or older & $10(23.8)$ \\
Marital status & \\
Married & $23(54.8)$ \\
Single & $14(33.3)$ \\
Widow & $1(2.4)$ \\
Separated/divorced & $4(9.5)$ \\
\hline
\end{tabular}


Table 1 - Cont.

\begin{tabular}{lc}
\hline Variables & $\mathbf{N}(\%)$ \\
\hline Family arrangement & $2(4.8)$ \\
Lives alone & $7(16.7)$ \\
Lives with spouse only & $12(28.6)$ \\
Lives with spouse and family members & $21(50.0)$ \\
Lives with family members & \\
Formal education & $2(4.8)$ \\
Less than 4 years & $10(23.8)$ \\
4 - 7 years & $10(23.8)$ \\
8 - 10 years & $20(47.6)$ \\
11 or more years & \\
Personal Income & $29(69.0)$ \\
$\mathrm{R} \$ 880,00$ & $3(7.1)$ \\
$\mathrm{R} \$ 1,7600$ & $2(4.8)$ \\
More than $\mathrm{R} \$ 1,760$ & $8(19.0)$ \\
No income & \\
Family Income & $1(2.6)$ \\
Less than $\mathrm{R} \$ 880$ & $13(33.3)$ \\
$\mathrm{R} \$ 880$ & $17(43.6)$ \\
$\mathrm{R} \$ 1,760$ & $8(20.5)$ \\
More than $\mathrm{R} \$ 1760$ & \\
Social security situation & $10(23.8)$ \\
Retired & $22(52.4)$ \\
IIIness-benefit & $10(23.8)$ \\
None &
\end{tabular}

Table 2 - Proportion of correct answers related to textual comprehension and numeracy of the individuals undergoing dialysis therapy. Recife, PE, Brazil, 2016. $(n=42)$

\begin{tabular}{lc}
\hline Variables & $\begin{array}{c}\text { Number of correct answers } \\
\mathbf{N}(\%)\end{array}$ \\
\hline Correct alternatives in textual comprehension & \\
$0-18$ & $29(80.5)$ \\
$19-27$ & $8(22.2)$ \\
$28-36$ & $5(13.8)$ \\
Numeracy* & \\
Medication interval times & $30(71.4)$ \\
Glycemic values & $29(69.0)$ \\
Consultation scheduling & $32(76.2)$ \\
Guidance for medication use & $13(30.9)$ \\
\hline
\end{tabular}

* Multiple answers

Among the independent variables, only marital status $(p$-value $=0.018)$ and personal income $(p$-value $=0.009)$ were factors associated with the worst scores in the test, indicating that these 
variables influence the increase in inadequate literacy (Table 3). However, in the clinical profile, the independence test was not significant among the variables, suggesting that these variables do not interfere in the levels of inadequate literacy (Table 4).

Table 3 - Level of literacy according to the sociodemographic profile of individuals undergoing dialysis therapy. Recife, PE, Brazil, 2016. $(n=42)$

\begin{tabular}{|c|c|c|c|}
\hline \multirow[b]{2}{*}{ Variables } & \multicolumn{2}{|c|}{ Literacy level } & \multirow[b]{2}{*}{ p-value* } \\
\hline & $\begin{array}{c}\text { Inadequate } \\
\mathrm{n}(\%)\end{array}$ & $\begin{array}{c}\text { Adequate } \\
\mathrm{n}(\%)\end{array}$ & \\
\hline \multicolumn{4}{|l|}{ Sex } \\
\hline Male & $14(87.5)$ & $2(12.5)$ & 0.688 \\
\hline Female & $20(76.9)$ & $6(23.1)$ & \\
\hline \multicolumn{4}{|l|}{ Age } \\
\hline $23-40$ years of age & $13(76.5)$ & $4(23.5)$ & 0.787 \\
\hline $41-59$ years of age & $12(80.0)$ & $3(20.0)$ & \\
\hline 60 years of age or older & $9(90.0)$ & $1(10.0)$ & \\
\hline \multicolumn{4}{|l|}{ Marital status } \\
\hline Married & $22(95.7)$ & $1(4.3)$ & 0.018 \\
\hline Single & $9(64.3)$ & $5(35.7)$ & \\
\hline Widowed & $1(100.0)$ & $0(0.0)$ & \\
\hline Separated / divorced & $2(50.0)$ & $2(50.0)$ & \\
\hline \multicolumn{4}{|l|}{ Family arrangement } \\
\hline Lives alone & $1(50.0)$ & $1(50.0)$ & \\
\hline Lives with spouse only & $7(100.0)$ & $0(0.0)$ & 0.162 \\
\hline Lives with spouse and family members & $11(91.7)$ & $1(8.3)$ & \\
\hline Family members & $15(71.4)$ & $6(28.6)$ & \\
\hline \multicolumn{4}{|l|}{ Formal education } \\
\hline Less than 4 years & $2(100.0)$ & $0(0.0)$ & \\
\hline $4-7$ years & $10(100.0)$ & $0(0.0)$ & 0.113 \\
\hline $8-10$ years & $9(90.0)$ & $1(10.0)$ & \\
\hline 11 years or more & $13(65.0)$ & $7(35.0)$ & \\
\hline \multicolumn{4}{|l|}{ Personal income } \\
\hline $\mathrm{R} \$ 880$ & $27(93.1)$ & $2(6.9)$ & 0.009 \\
\hline $\mathrm{R} \$ 1,760$ & $1(33.3)$ & $2(66.7)$ & \\
\hline More than $\mathrm{R} \$ 1,760$ & $1(50.0)$ & $1(50.0)$ & \\
\hline No income & $5(62.5)$ & $3(37.5)$ & \\
\hline \multicolumn{4}{|l|}{ Family income } \\
\hline Less than $\mathrm{R} \$ 880$ & $1(100.0)$ & $0(0.0)$ & 0.684 \\
\hline $\mathrm{R} \$ 880$ & $12(92.3)$ & $1(7.7)$ & \\
\hline $\mathrm{R} \$ 1,760$ & $14(82.4)$ & $3(17.6)$ & \\
\hline More than $\mathrm{R} \$ 1,760$ & $6(75.0)$ & $2(25.0)$ & \\
\hline \multicolumn{4}{|l|}{ Social security situation } \\
\hline Retired & $8(80.0)$ & $2(20.0)$ & 0.525 \\
\hline Illness-benefit & $19(86.4)$ & $3(13.6)$ & \\
\hline None & $7(70.0)$ & $3(30.0)$ & \\
\hline
\end{tabular}

${ }^{*}$ Fisher's exact Test 
Table 4 - Level of literacy according to the clinical profile of individuals undergoing to dialysis therapy. Recife / PE, 2016. $(n=42)$

\begin{tabular}{lccc}
\hline & \multicolumn{2}{c}{ Literacy Level } & \\
\cline { 2 - 3 } Variables & $\begin{array}{c}\text { Inadequate } \\
\mathbf{n}(\%)\end{array}$ & $\begin{array}{c}\text { Adequate } \\
\mathbf{n}(\%)\end{array}$ & p-value* \\
\hline Dialysis modality & & & \\
Haemodialysis & $23(76.7)$ & $7(23.3)$ & 0.402 \\
Diálise peritoneal & $11(91.7)$ & $1(8.3)$ & \\
Underlying disease & & & \\
Hypertension & $10(76.9)$ & $3(23.1)$ & 0.384 \\
Diabetes & $0(0.0)$ & $1(100.0)$ & \\
Hypertension and diabetes & $2(100.0)$ & $0(0.0)$ & \\
Systemic lupus erythematosus & $5(71.4)$ & $2(28.6)$ & \\
Glomerulonephritis & $3(100.0)$ & $0(0.0)$ & \\
Others & $14(87.5)$ & $2(12.5)$ & \\
Comorbidities & & & \multirow{2}{*}{0.405} \\
Hypertension & $29(78.4)$ & $8(21.6)$ & \\
Diabetes & $4(66.7)$ & $2(33.3)$ & \\
Cardiovascular & $4(66.7)$ & $2(33.3)$ & \\
Dyslipidemia & $3(60.0)$ & $2(40.0)$ & \\
Ophthalmologic & $2(50.0)$ & $2(50.0)$ & \\
Autoimmune & $1(33.4)$ & $2(66.6)$ & \\
\hline
\end{tabular}

* Fisher exact test

\section{DISCUSSION}

Inadequate functional health literacy was the most prevalent among patients with nephropathy associated with marital status and personal income. A similar population study also found a limited literacy level of $10-50 \%$ among participants. ${ }^{14}$ Inadequate $\mathrm{FHL}$ may contribute to worse health outcomes in chronic kidney patients due to knowledge, attitude, and behavior. ${ }^{11}$

It is important to highlight that FHL depends on multiple determinants inherent to individuals, such as sociodemographic characteristics, cognitive abilities and physical abilities, which interact with one another when considering the educational system, health system, cultural and social context. Such factors may make those individuals with little formal education, who are poorer and older more vulnerable, ${ }^{15}$ such as those found in this research.

Most patients had difficulty when they needed to read the whole sentence, process information within the context of the questionnaire and identify the word that matched their meaning as well as simultaneously understanding the text in a timely manner. The average o correct answers between 0-18 questions had a prevalence of $80.5 \%$. In this context, it is worth mentioning that the research using Functional Health Literacy Indicator, an instrument that evaluates literacy in Brazil in general, revealed worrying numbers. Among Brazilians aged 15-64, 27\% were classified as functionally illiterate. $67 \%$ of those interviewed who did not attend school or had an average of 04 years of formal education, were classified as functionally illiterate; $32 \%$ of those who had an average of 7 years of formal education were classified as having a rudimentary grade of literacy, i.e., able to locate one or more explicit pieces of information in shorts texts or perform simple mathematical sums. ${ }^{16}$ 
In the numeracy step, the card that had the highest number of correct answers was related to the appointments, while the lower prevalence was related to the use of medication at the correct time. A reality that is reflected in the adherence to treatment and effective therapeutic management. ${ }^{13} \mathrm{~A}$ positive association between formal education and scoring in the literacy test is noted. In this research, a greater number of correct answers were found in the reading and numeracy comprehension of patients with an average of 11 years or more of formal education.

When the level of literacy in relation to sociodemographic variables is verified, the result can be compared with a study carried out in the city of São Paulo, Brazil, with 312 healthy participants, with a mean age of 47.3 years and 9.7 years of formal education. However, in this study, $32.4 \%$ of the sample had a literacy deficit with this rate reaching $51.6 \%$ among the elderly participants. ${ }^{13}$

In relation to age, this result may be a reflection of the underlying disease itself and the physiological process of aging. Some studies have shown that cognitive impairment is associated with CRD severity and that in general, there is a higher prevalence in patients undergoing hemodialysis. ${ }^{17}$ In the same group, the highest percentage of correct answers was in the second stage of the questionnaire, numeracy, a fact which can be explained by the greater ease and more didactic presentation of the material used, which was related to the therapy maintenance.

Another study, conducted with 480 patients on haemodialysis therapy who were followed up for 12 months, identified that $32 \%$ of the patients had inadequate $\mathrm{FHL}$, which were associated more frequently with males and lower levels of formal education. Patients with inadequate FHL had a higher risk of death when compared to individuals with adequate FHL. ${ }^{18}$

Among the conditions studied, the variables marital status and personal income were associated with the level of inadequate literacy. The relevance found for the situation of the widowed participants may be a reflection of the sample number and may suggest a pseudo-positive result. The married variable may be related to the transfer of responsibilities from the therapeutic process to the spouse. However, there are no direct scientific reports that indicate that this situation is related to literacy level. Personal income is considered an external determinant, as is employment, social support, and cultural level. ${ }^{10}$ In general, those with higher incomes have more alternative sources of knowledge. ${ }^{19}$ Low income, coupled with other aggravating social factors, directly impairs the level of education and processing of information. ${ }^{20}$

In relation to underlying CRD disease and association of comorbidity, systemic arterial hypertension ( $\mathrm{SAH}$ ) has also been found in other studies. ${ }^{21-22} \mathrm{SAH}$ has become a national and worldwide public health problem and is considered a ubiquitous condition in CRD, and can be considered a cause and consequence of such pathology. ${ }^{23}$

The choice of the dialysis modality is associated with several factors, and it is of fundamental importance that the patient knows the types of treatments offered for a joint definition of the treatment, associated with the clinical condition of the patient and the doctor's evaluation ${ }^{6}$. In this study, the prevalent dialysis therapy was haemodialysis. These results may be associated to an exclusively medical decision, due to the patient's clinical conditions, as well as other variables related to the social condition, such as a lack of education regarding pre-dialysis. ${ }^{24}$

PD is a method used by approximately 120,000 patients worldwide and its use is increasing due to its simplicity and suitability. However, it is not widely used when compared to haemodialysis. ${ }^{6}$ In Brazil, the mean number of patients performing this type of treatment is only $9 \%$, differing from the $28.6 \%$ found in the present study, compared with the national level. ${ }^{3}$ It is suggested that this finding may be a reflection of the health team's performance in the institution under study, by presenting the patient to the two dialytic modalities and being an reference institution in the area. 
However, there was a predominance of inadequate literacy in patients with PD and who had a history of other substitutive renal therapies; this result, even without significant relevance, reveals concerns on the part of the health team.

The need for good self-care practices and knowledge about the health-disease process, basic pillars for the individual to manage his/her health condition, and consequently to decide on the procedures that allow the success of the treatment, are evident. ${ }^{24}$ It is believed that this result may be a reflection of the transfers of responsibilities that the patient passes on to the family member/caregiver.

A limitation of the study concerns the small number of participants, as well as the scarcity of scientific literature on FHL in this public. Another limitation of the study is the non-application of the cognitive function screening test to the study participants, with only the registration of this condition in medical records being considered. This particular test is recommended in the literature in order to improve the interpretation of the $\mathrm{FHL}$ level assessment tests results. ${ }^{25}$

\section{CONCLUSION}

The results demonstrate a high prevalence of inadequate functional literacy, reflecting difficulties in understanding and processing health information, which may interfere with therapeutic management and self - care.

Thus, special attention is needed in the exchange of information, associated with an improvement in the education system, with a view to the proper management of the health-disease process. It is important that health professionals know the level of literacy of their patients, so the exchange of information occurs in a clear and objective way. In this context, nurses are fundamental in the provision of direct patient care and become facilitators for health education.

As this is a subject that has not yet been explored in this population, it is necessary to expand the application of specific questionnaires, allowing health professionals to be more attentive regarding FHL.

\section{REFERENCES}

1. Silva NK, Sartori DL, Zink V, Aguiar RB, Schirmer J. A vivência de pacientes que necessitam de transplante renal na espera por um órgão compatível. Texto Contexto Enferm [Internet]. 2013 [cited 2017 Mar 18];22(4):1160-8. Available from: http://dx.doi.org/10.1590/S0104-07072013000400035

2. Kidney International Supplements. [Internet]. 2013;3(1):1-150. Available from: https://www. kisupplements.org/issue/S2157-1716(13)X3100-4

3. Sesso RC, Lopes AA, Thomé FS, Lugon JR, Martins CT. Brazilian Chronic Dialysis Survey 2016. J Bras Nefrol [Internet]. 2017 [cited 2017 Mar 25];39(3):261-6. Available from: http://dx.doi.org/ 10.5935/0101-2800.20170049

4. Louvison MCP, Cecilio MAM, Osiano VLLR, Portas SLC, Sesso R. Prevalence of substitute renal therapy in the State of São Paulo. Bol Epidemiol Paul [Internet]. 2011 [cited 2017 Abr 15];8(95):120. Available from: http://periodicos.ses.sp.bvs.br/scielo.php?script=sci_arttext\&pid=S180642722011001100004\&lng=es\&nrm=iso\&tlng=pt

5. Lins SMSM, Santo FHR, Fuly PSC, Garcia TR. Subconjunto de conceitos diagnósticos da CIPE® para portadores de doença renal crônica. Rev Bras Enferm [Internet]. 2013 [cited 2017 Mar 05];66:1-10. Available from: http://dx.doi.org/10.1590/S0034-71672013000200005

6. Daurgidas JT, Blake PG, Ing TS. Manual de diálise. 4th ed. Rio de Janeiro, RJ: Guanabara Koogan;2013:24. 
7. Gesualdo GD, Menezes ALC, Rusa SG, Napoleão AA, Figueiredo RM, Melhado VR, et al. Factors associated with quality of life for hemodialysis patients. Texto Contexto Enferm [Internet]. 2017 https://doi.org/10.1590/0104-07072017005600015

8. Cavanaugh KL. Health literacy in diabetes care: explanation, evidence and equipment. Diabetes Manag (Lond). 2011 Mar [cited 2017 Jun 03];1(2):191-9. Available from: https://www.ncbi.nlm. nih.gov/pmc/articles/PMC3158575/ https://doi.org/10.2217/dmt.11.5

9. Sorensen K, Van den Broucke S, Fullam J, Doyle G, Pelikan J, Slonska S, et al. Health literacy and public health: a systematic review and integration of definitions and models. BMC Publ Health [Internet]. 2012 https://doi.org/10.1186/1471-2458-12-80

10. Santos LTM, Mansur HN, Paiva TFPS, Colugnati FAB, Bastos MG. Letramento em saúde: importância da avaliação em nefrologia. J Bras Nefrol [Internet]. 2012 [cited 2017 Aug 02];34:110. Disponível em: http://dx.doi.org/10.5935/0101-2800.20120014

11. Moraes KL, Brasil VV, Oliveira GF, Cordeiro JABL, Silva AMTC, Boaventura RP, et al. Functional health literacy and knowledge of renal patients on pre-dialytic treatment Rev Bras Enferm [Internet]. 2017 [cited 2017 Aug 03];70(1):147-53. Available from: http://www.scielo.br/pdf/reben/v70n1/00347167-reben-70-01-0155.pdf

12. Marques SRL, Lemos SMA. Health literacy assessment instruments: literature review. Audiol Commun Res [Internet]. 2017 [cited 2017 Dec 02];22::e1757. Available from: http://www.scielo. br/scielo.php?pid=S2317-64312017000100501\&script=sci_abstract\&tlng=pt

13. Carthery-Goulart MT, Anghinah R, Areza-Fegyveres R, Bahia VS, Brucki SMD, Damin A, et al. Performance of a Brazilian population on the test of functional health literacy in adults. Rev Saúde Públ [Internet]. 2009 https://doi.org/10.1590/S0034-89102009005000031

14. Dageforde LA, Cavanaugh KL. Health Literacy: emerging evidence and applications in Kidney Disease care. Adv Chronic Kidney Dis [Internet]. 2013 [cited 2017 Mar 25];20(4):311-9. Available from: http://dx.doi.org/10.1053/j.ackd.2013.04.005

15. Santos MIPO, Portella MR, Scortegagna HM, Santos PCS. Functional health literacy from the perspective of gerontological nursing: an integrative literature review. Rev Bras Geriat Gerontol [Internet]. 2015 [cited 2017 Aug 02];18(3):651-64. Available from: http://dx.doi.org/10.1590/18099823.2015.14080

16. Instituto Paulo Montenegro. Indicador de alfabetismo funcional - INAF: estudo especial sobre alfabetismo e mundo do trabalho [Internet]. 2016 [cited 2017 Mar 05]. Available from: http:// acaoeducativa.org.br/wp-content/uploads/2016/09/INAFEstudosEspeciais_2016_Letramento_e_ Mundo_do_Trabalho.pdf

17. Stringuetta-Belik F, Martin LC, Franco RJS. Cognitive impairment in chronic kidney disease. J Bras Nefrol [Internet]. 2014 [cited 2017 Feb 08];36(2): 116-7. Available from: http://dx.doi. org/10.5935/0101-2800.20140018

18. Cavanaugh KL, Wingard RL, Hakim RM, Eden S, Shintani A, Wallston KA, et al. Low health literacy associates with increased mortality in ESRD. J Amer Soc Nephrol [Internet]. 2010 [cited $2017 \mathrm{FeV}$ 03];21(11):1979-85. Available from: http://dx.doi.org/10.1681/ASN.2009111163

19. Sun X, Shi Y, Zeng Q, Wang Y, Du W, Wei N, et al. Determinants of health literacy and health behavior regarding infectious respiratory diseases: a pathway model. BMC Publ Health [Internet]. 2013 [cited 2017 Feb 05];13(1):1-10. Available from: http://dx.doi.org/10.1186/1471-2458-13-261

20. Rocha PC, Lemos SMA. Conceptual aspects and factors associated with functional health literacy: a literary review. Rev Cefac [Internet]. 2016 [cited 2017 Jan 28];18(1):214-25. Available from: http://dx.doi.org/10.1590/1982-021620161819615 
21. Telles CT, Dobner T, Pomatti G, Fortes VF, Brock F, Bettinelli LA. Socio-demographic, clinical and laboratory profile of patients submitted to hemodialysis. Rev Rede Enferm NE. 2014 [cited 2017 Fev 28];15(03):420-6. Available from: http://dx.doi.org/10.15253/2175-6783.2014000300006

22. Ottaviani AC, Betoni LC, Pavarini SCI, Say KG, Zazzetta MS, Orlandi FS. Association between anxiety and depression and quality of life of chronic renal patients on hemodialysis. Texto Contexto Enferm [Internet]. 2016 [cited 2017 Mar 20];25(3):1-8. Available from: http://dx.doi.org/10.1590/010407072016000650015

23. Pinho NA, Silva GV, Pierin AMG. Prevalence and factors associated with chronic kidney disease among hospitalized patients in a university hospital in the city of São Paulo, SP, Brazil. J Bras Nefrol [Internet]. 2015 [cited 2017 Mar 15];37(1):91-7. Available from: http://dx.doi.org/10.5935/01012800.20150013

24. Lorig K. Living a healthy life with chronic conditions: self - management of heart disease, arthritis, diabetes, depression, asthma, bronchitis, emphysema, and other physical and mental health conditions. 4th ed. Boulder, US: Bull Publishing Company;2012:15.

25. Dahlke AR, Curtis LM, Federman AD, Wolf MS. The mini mental status exam as a surrogate measure of health literacy. J Gen Int Med [Internet]. 2014 [cited 2017 Mar 25];29(4):615-20. Available from: http://dx.doi.org/10.1007/s11606-013-2739-z 


\section{NOTES}

\section{ORIGIN OF THE ARTICLE}

Extracted from Undergraduate Thesis - Health Literacy of individuals undergoing dialysis therapy, presented to the Programa de Residência em Enfermagem of the Hospital das Clinicas of the Universidade Federal de Pernambuco (UFPE), in 2016.

\section{CONTRIBUTION OF AUTHORITY}

Study design: Bezerra JNM, Borba AKOT.

Data collect: Bezerra JNM, Lessa SRO, do Ó MF, Borba AKOT.

Data analysis and interpretation: Bezerra JNM, Luz GOA, Borba AKOT.

Discussion of the results: Bezerra JNM, Luz GOA, Borba AKOT.

Writing and/or critical review of content: Bezerra JNM, Lessa SRO, do Ó MF, Luz GOA, Borba AKOT. Review and final approval of the final version: Bezerra JNM, Lessa SRO, do Ó MF, Luz GOA, Borba AKOT.

\section{ACKNOWLEDGMENTS}

We would like to thank the Hospital das Clínicas of the Universidade Federal de Pernambuco for opening their doors so that it would be possible to carry out this work. Dr. Lucila Maria Valente and Nurse Analú Pedrosa de Souza Quirino for hosting the researchers at the nephrology unit of the hospital.

\section{FUNDING INFORMATION}

Not applicable

\section{ETHICS COMMITTEE IN RESEARCH}

Approved by the Ethics Committee in Research with Human Beings of the Centro de Ciências da Saúde, Universidade Federal de Pernambuco, N. 2003622 and Certificate of Presentation for Ethical Appreciation, N. 51953815.0.0000.5208.

\section{CONFLICT OF INTEREST}

No any conflict of interest.

\section{CONSENT OF USE OF IMAGE}

Not applicable.

\section{HISTORICAL}

Received: December 11, 2017.

Approved: April 13, 2018.

\section{CORRESPONDENCE AUTHOR}

Jéssica Naylla de Melo Bezerra jessicanaylla.melo@gmail.com 